\title{
MODEL PEMBELAJARAN INSIDE OUTSIDE CIRCLE (IOC)) UNTUK MENINGKATKAN HASIL BELAJAR SISWA DALAM PROSES PEMBELAJARAN
}

\author{
NURUL AZMI \\ *Dosen Jurusan Tadris Biologi FITK IAIN Syekh Nurjati Cirebon
}

\begin{abstract}
ABSTRAK
Kegiatan proses pembelajaran di sekolah yang hanya terpusatkan pada guru, mengakibatkan kurang efektif dan kurang mencapai sasaran pencapaian tujuan pembelajaran serta masih belum tercapainnya hasil belajar siswa yang maksimal dan memenuhi standar $\mathrm{kkm} 75$. Untuk itu berbagai upaya harus dilakukan untuk mencapai kegiatan belajar yang efektif, terarah dan bermanfaat. Upaya praktis yang mungkin dapat dilakukan yakni penggunaan model pembelajaran Model pembelajaran yang merupakan salah satu komponen utama dalam menciptakan suasana pembelajaran yang aktif, inovatif dan menyenangkan. Model pembelajaran yang menarik dan variatif akan berimplikasi pada minat maupun motivasi peserta didik dalam mengikuti proses pembelajaran di kelas. Model pembelajaran Inside Outside Circle memiliki struktur yang jelas, siswa juga dapat bekerja dengan sesama siswa dengan suasana gotong -royong dan mempunyai banyak kesempatan untuk mengolah informasi dan meningkatkan keterampilan berkomunikasi.

Model pembelajaran inside outside circle dalam pembelajaran mampu meningkatkan hasil belajar siswa dengan didukung sikap siswa yang setuju pada penggunaan model pembelajaran inside outside circle.
\end{abstract}

Kata kunci : model pembelajaran, inside outside circle, hasil belajar.

\section{A. PENDAHULUAN}

Pendidikan pada dasarnya merupakan interaksi antara pendidik dan peserta didik, untuk mencapai tujuan pendidikan. Pendidikan merupakan proses dasar dari perkembangan hidup manusia. Karena dengan belajar, manusia melakukan perubahan kualitas hidup sehingga tingkah lakunya berkembang. Belajar itu bukan hanya sekedar pengalaman, namun juga belajar merupakan suatu proses dan bukan suatu hasil. Karena semua aktivitas dan prestasi hidup manusia tidak lain adalah hasil dari belajar. Oleh karena itu belajar harus berlangsung secara aktif dan integratif dengan menggunakan berbagai bentuk perbuatan untuk mencapai suatu tujuan (Soemanto, 2004:104). 
Perubahan paradigma pada sistem pendidikan nasional dari pengajaran menjadi pembelajaran mengisyaratkan bahwa proses pembelajaran bukan hanya sekedar proses transfer ilmu pengetahuan, tetapi pembelajaran menuntut siswa lebih aktif dalam mengembangkan pengetahuannya. Seiring dengan kemajuan teknologi komunikasi dan informasi yang sangat pesat, keberhasilan kegiatan belajar mengajar tidak hanya ditentukan oleh faktor pengajar, melainkan sangat dipengaruhi oleh keaktifan siswa dalam mencari bahan ajar. Kurikulum 2013 mempertegas bahwa proses pembelajaran harus berpusat pada peserta belajar (student center), pengajar bukan sebagai satu-satunya sumber belajar atau sumber informasi, melainkan juga berperan sebagai fasilitator, dinamisator, dan motivator dalam pembelajaran, sehingga pendidik dituntut melakukan tindakan strategi kreatif dan inovatif dalam pada usaha pencapaian tujuan pembelajaran, yakni membentuk siswa yang mandiri, mampu merangsang siswa mengembangkan intelektualnya, tetapi pada kenyataanya masih banyak ditemui proses pembelajaran yang tidak efektif dan efisien sehingga kurang mempunyai daya tarik terhadap siswa bahkan cenderung monoton dan membosankan, akibatnya hasil belajar yang dicapai tidak optimal.

Kegiatan pembelajaran disekolah yang hanya terpusat pada guru, mengakibatkan kurang efektif dan kurang mencapai sasaran pencapaian tujuan pembelajaran serta masih belum tercapainnya hasil belajar siswa yang memenuhi standar kkm yang telah ditentukan oleh sekolah yakni 75 . Untuk itu berbagai upaya harus dilakukan untuk mencapai kagiatan belajar yang efektif, terarah dan bermanfaat.Upaya praktis yang mungkin dapat dilakukan yakni penggunaan model pembelajaran.Model sangat penting peranannya dalam pembelajaran, karena melalui pemilihan model yang tepat dapat mengarahkan guru pada kualitas pembelajaran efektif.Model pembelajaran merupakan cara/teknik penyajian yang digunakan guru dalam proses pembelajaran agar tercapai tujuan pembelajaran. Pengertian Model Pembelajaran dapat diartikan sebagai cara, contoh maupun pola, yang mempunyai tujuan meyajikan pesan kepada siswa yang harus diketahui, 
dimengerti, dan dipahami yaitu dengan cara membuat suatu pola atau contoh dengan bahan-bahan yang dipilih oleh para pendidik/guru sesuai dengan materi yang diberikan dan kondisi di dalam kelas.

Model pembelajaran merupakan salah satu komponen utama dalam menciptakan suasana yang aktif, inovatif dan menyenangkan. Model pembelajaran yang menarik dan variatif akan berimplikasi pada minat maupun motivasi peserta didik dalam mengikuti proses belajar mengajar di kelas.Dengan menerapkan kurikulum KTSP dan tuntutan untuk mengembangkan model pembelajaran kreatif guru harus pula mampu mengikuti tuntutan perkembangan dunia pendidikan terkini. Guru harus mencoba untuk lebih banyak menggunakan model pembelajaran dalam kegiatan belajar mengajarnya, agar mampu membimbing peserta didik untuk lebih mengembangkan dan mengeksplorasi ilmu yang dimiliki.

Model pembelajaran Inside Outside Circle adalah model pembelajaran yang dikembangkan oleh (Kagan, 1993). Model pembelajaran dengan sistem lingkaran kecil dan lingkaran besar, dimana siswa saling membagi informasi pada saat yang bersamaan dengan pasangan yang berbeda dengan singkat dan teratur.Model pembelajaran Inside Outside Circle memilki struktur yang jelas, siswa juga dapat bekerja dengan sesame siswa dengan suasana gotong royong dan mempunyai banyak kesempatan untuk mengolah informasi dan meningkatkan keterampilan berkomunikasi.

Selaras dengan tuntutan yang harus dijalani sebagai seorang tenaga pengajar yakni harus bisa membangkitkan semangat belajar siswa, kemampuan berpikir, dan rasa gotong-royong sesama siswa dan selalu berinovasi dalam setiap kegiatan pembelajaran karena perkembangan dunia pendidikan sekarang sudah sangat modern, tidak bisa hanya terpusat oleh guru karena hal tersebut cenderung membuat peserta didik pasif. Oleh karena itu, penggunaan model pembelajaran Inside Outside Circle dirasa sangat cocok untuk membantu dalam kegiatan pembelajaran siswa dalam meningkatan hasil belajar siswa, minat belajar dan mengasah kemampuan berfikir, berbicara, dan bekerjasama sehingga suasana pembelajaran pun lebih efektif. 
Hal ini dapat terlihat dari gambaran rangkaian model pembelajaran Inside Outside Circle yang memiliki struktur penerapan yang jelas.

\section{B. MODEL PEMBELAJARAN INSIDE OUTSIDE CIRCLE}

Menurut Komaruddin (2000) bahwa model pembelajaran dapat diartikan sebagai kerangka konseptual yang digunakan sebagai pedoman dalam melakukan kegiatan. Model dapat dipahami sebagai :

a. suatu tipe atau desain

b. suatu deskripsi atau analogi yang dipergunakan untuk membantu proses visualisasi sesuatu yang tidak dapat dengan langsung diamati

c. suatu sistem asumsi-asumsi, data-data, dan inferensi-inferensi yang dipakai untuk menggambarkan secara matematis suatu obyek peristiwa

d. suatu desain yang disederhanakan dari suatu sistem kerja, suatu terjemahan realitas yang disederhanakan

e. suatu deskripsi dari suatu sistem yang mungkin atau imajiner

f. penyajian yang diperkecil agar dapat menjelaskan dan menunjukan sifat bentuk aslinya.

1. Pengertian model Pembelajaran Inside Outside Circle

Model Pembelajaran Lingkaran dalam dan Luar Inside-outside circle (IOC) adalah model pembelajaran dengan sistem lingkaran kecil dan lingkaran besar (Kagan, 1993), dimana siswa saling membagi informasi pada saat yang bersamaan dengan pasangan yang berbeda dengan singkat dan teratur. Model mengajar lingkaran besar dan lingkaran kecil (insideoutside circle) dikembangkan oleh Kagan untuk memberikan kesempatan pada siswa agar saling berbagi informasi pada saat yang bersamaan.

Menurut Lie (2008:65), model pembelajaran IOC adalah model pembelajaran yang dikembangkan oleh Spencer Kagan untuk memberikan kesempatan pada siswa agar saling berbagi informasi pada saat yang bersamaan. Pendekatan ini bisa digunakan dalam beberapa mata pelajaran, seperti: ilmu pengetahuan sosial, agama, matematika, dan bahasa. Bahan 
pelajaran yang paling cocok digunakan dengan model IOC ini adalah bahan yang membutuhkan pertukaran pikiran dan informasi antar siswa.

Keunggulan dari model pembelajaran IOC adalah adanya struktur yang jelas dan memungkinkan siswa untuk berbagi dengan pasangan yang berbeda dengan singkat dan teratur. Selain itu, siswa bekerja dengan sesama siswa dalam suasana gotong-royong dan mempunyai banyak kesempatan untuk mengolah informasi dan meningkatkan keterampilan berkomunikasi. Model IOC ini juga dapat di gunakan untuk semua tingkat usia anak didik dan mata pelajaran apa saja.

Menurut Suyatno (2009; 69) Model pembelajaran IOC (Inside Outside Circle) adalah model pembelajaran dengan sistem lingkaran kecil dan lingkaran besar dimana siswa saling membagi informasi pada saat yang bersamaan dengan pasangan yang berbeda dengan singkat dan teratur. Sintaknya adalah separuh dari sejumlah siswa membentuk lingkaran kecil mengahadap keluar, separuhnya lagi membentuk lingkaran besar mengahadap ke dalam, siswa yang berhadapan berbagi informasi secara bersamaan, siswa yang berada di lingkaran luar berputar kemudian berbagi informasi kepada teman (baru) di depannya, dan seterusnya.Pada model ini, siswa saling membagi informasi pada saat yang bersamaan, dengan pasangan yang berbeda dengan singkat dan teratur.

Jadi dapat disimpulkan bahwa model pembelajaran IOC adalah model pembelajaran dengan sistem dua lingkaran yakni lingkaran luar dan lingkaran dalam sehingga siswa membentuk posisi yang saling berhadapan setelah itu siswa saling berbagi informasi, pemberian informasi dimulai dari siswa yang berada di lingkaran dalam. Agar informasi yang di dapat bisa lebih banyak dan beragam maka dilakukan perputaran sehingga membentuk pasangan yang baru. Hal tersebut mungkin dimaksudkan agar siswa aktif dan diharapkan mampu untuk bekerja secara individu maupun bekerja secara tim.

2. Langkah-langkah / sintaks Model Pembelajaran IOC 
Menurut Kagan, ada lima langkah utama dalam penerapan model IOC ini, yaitu:

a. Langkah pertama, separuh kelas berdiri membentuk lingkaran kecil dan menghadap keluar.

b. Langkah kedua, separuh kelas lainnya membentuk lingkaran di luar lingkaran pertama dan menghadap ke dalam.

c. Langkah ketiga, kemudian dua siswa yang berpasangan dari lingkaran kecil dan besar berbagi informasi. Pertukaran informasi ini bisa dilakukan oleh semua pasangan dalam waktu yang bersamaan.

d. Langkah keempat, siswa yang berada di lingkaran kecil diam di tempat, sementara siswa yang berada di lingkaran besar bergeser satu atau dua langkah searah jarum jam, sehingga masing-masing siswa mendapatkan pasangan baru.

e. Langkah terakhir, giliran siswa yang berada di lingkaran besar yang membagi informasi. Demikian seterusnya.

Lie dalam Kagan (2008:66), dalam pengembangan siswa dalam kelas dibagi menjadi dua lingkaran, yaitu lingkaran individu dan lingkaran kelompok. Penjelasannya sebagai berikut:

a. Lingkaran individu

1) Separuh kelas (atau seperempat jika jumlah siswa terlalu banyak) berdiri membentuk lingkaran kecil. Mereka berdiri melingkar dan menghadap keluar.

2) Separuh kelas lainnya membentuk lingkaran di luar lingkaran yang pertama. Dengan kata lain, mereka berdiri menghadap ke dalam dan berpasangan dengan siswa yang berada di lingkaran dalam.

3) Dua siswa yang berpasangan dari lingkaran kecil dan lingkaran besar berbagi informasi. Siswa yang berada di lingkaran kecil yang memulai. Pertukaran informasi ini bisa dilakukan oleh semua pasangan dalam waktu yang bersamaan.

4) Kemudian, siswa yang berada di lingkaran kecil diam di tempat, sementara siswa yang berada di lingkaran besar bergeser satu atau 
dua langkah searah perputaran jarum jam. Dengan cara ini, masingmasing siswa mendapatkan pasangan baru untuk berbagi informasi.

5) Sekarang giliran siswa yang berada di lingkaran besar yang membagikan informasi. Demikian seterusnya.

b. Lingkaran kelompok

1) Satu kelompok berdiri di lingkaran kecil menghadap keluar. Kelompok yang lain berdiri di lingkaran besar.

2) Kelompok berputar seperti prosedur lingkaran individu yang dijelaskan di atas dan saling berbagi.

Menurut Menurut Suyatno (2009:69) Langkah-langkahnya model pembelajaran adalah sebagai berikut.

a. Separuh kelas berdiri membentuk lingkaran kecil dan menghadap keluar.

b. Separuh kelas lainnya membentuk lingkaran di luar lingakran pertama, menghadap ke dalam.

c. Dua siswa yang berpasangan dari lingkaran kecil dan besar berbagi informasi. Pertukaran informasi ini bisa dilakukan oleh semua pasangan dalam waktu yang bersamaan.

d. Kemudian siswa berada di lingkaran kecil diam di tempat, sementara siswa yang berada di lingkaran bergeser searah jarum jam.

e. Sekarang giliran siswa yang berada di lingkaran besar yang membagi informasi. Demikian seterusnya.

Dari beberapa pendapat yang di kemukakan dapat disimpulkan bahwa siswa dibagi menjadi dua kelompok lingkaran, setengah membetuk lingkaran menghadap keluar dan setengah lagi membentuk lingkaran menghadap kedalam namun seperti yang dikemukakan Lie bahwa jika jumlah siswa terlalu banyak maka seperempatnya saja. Pembagian informasi dimulai dari kelompok yang ada didalam, untuk mempersingkat waktu pembagian informasi dilakukan secara bersamaan, sedangkan untuk perputaran informasi selanjutnya dilakukan pada kelompok siswa yang berada diluar sehingga semua siswa bekerja, dst. 


\section{Kelebihan IOC:}

a. Mendapatkan informasi yang berbeda pada saat yang bersamaan.

b. Lebih banyak ide yang dapat di munculkan peserta didik

c. Mampu mempengaruhi motivasi, dan keaktifan peserta didik

d. Membantu menambah rasa percaya diri peserta didik

e. Membantu menilai kemampuan diri sendiri

f. Mengajak siswa untuk bisa berintaksi sehingga siswa tidak cenderung pasif

g. Memicu siswa untuk mau berfikir dan terampil berbicara

\section{Kekurangan IOC:}

c. Membutuhkan ruang kelas yang besar.

d. Terlalu lama sehingga tidak konsentrasi dan disalah gunakan untuk bergurau, juga rumit untuk dilakukan.

\section{Kegunaan Model Pembelajaran IOC}

Model pembelajaran merupakan strategi yang digunakan oleh guru untuk meningkatkan motivasi belajar, sikap belajar dikalangan siswa, mampu berpikir kritis, memiliki keterampilan sosial, dan pencapaian hasil pembelajaran yang lebih optimal (Isjoni, 2009: 8). Model pembelajaran terus mengalami perubahan dari model tradisional menuju model yang lebih modern.

Model pembelajaran berfungsi untuk memberikan situasi pembelajaran yang tersusun rapi untuk memberikan suatu aktivitas kepada siswa guna mencapai tujuan pembelajaran, suasana belajar menyenangkan, menambah rasa percaya diri siswa, siswa juga dapat menilai sejauh mana kemampuan dirinya, banyak ide-ide yang muncul, terampil berbicara, dan di harapkan mampu mempenngaruhi keaktifan serta motivasi belajar peserta didik.

Pengunaan model pembeljaran Inside Outside Circle dalam pembelajaran ini diharapkan mampu memberikan pencapaian optimal terhadap hasil belajar siswa dan mampu menghidupkan suasana kelas, dan kegiatan belajar-mengajar berjalan efektif, mampu membuat siswa aktif, 
membantu siswa untuk terampil berbicara, terampil dalam menggali kemampuan individu ataupun berkelompok.

\section{HASIL BELAJAR DAN FAKTOR-FAKTOR YANG MEMPENGARUHI}

1. Pengertian Hasil Belajar

Hasil belajar adalah angka yang diperoleh siswa yang telah berhasil menuntaskan konsep-konsep mata pelajaran sesuai dengan kriteria ketuntasan minimal (KKM) yang ditetapkan sesuai dengan kurikulum yang berlaku. Begitu juga hasil belajar dapat diartikan sebagai perubahan tingkah laku yang tetap sebagai hasil proses pembelajaran. Hasil belajar dapat diklasifikasikan menjadi tiga ranah, yaitu ranah kognitif, afektif, dan psikomotorik.

Prinsip yang mendasari penilaian hasil belajar yaitu untuk memberi harapan bagi siswa dan guru untuk dapat meningkatkan kualitas pembelajaran. Kualitas dalam arti siswa menjadi pembelajar yang efektif dan guru menjadi motivator yang baik. Dalam kaitan dengan itu, guru dan pembelajar dapat menjadikan informasi hasil penilaian sebagai dasar dalam menentukan langkah-langkah pemecahan masalah, sehingga mereka dapat memperbaiki dan meningkatkan belajarnya (Rasyid, 2008 : 67).

Menurut Hamalik (2001:159) bahwa hasil belajar menunjukan kepada prestasi belajar, sedangkan prestasi belajar itu merupakan indicator derajat perubahan tingkah laku siswa. Menurut Nasution (2006:36) hasil belajar adalah hasil dari suatu interaksi tindak belajar mengajar dan biasanya ditunjukan dengan nilai tes yang diberikan guru. Sedangkan menurut Dimyanti dan Modjiono (2002:36) hasil belajar adalah hasil yang ditunjukan dari suatu interaksi tindak belajar dan biasanya ditunjukan dengan tes yang diberikan guru.

Hasil belajar adalah kemampuan-kemampuan yang dimiliki siswa setelah ia menerima pengalaman belajarnya. Hasil belajar siswa hakikatnya adalah perubahan mencakup bidang kognitif, afektif dan psikomotoris yang berorientasi pada proses belajarnya yang dialami siswa. 
Dalam sistem pendidikan nasional, rumusan tujuan pendidikan menggunakan klasifikasi hasil belajar dari Benyamin Bloom yang secara garis besar membaginya menjadi tiga yakni ranah kognitif, ranah afektif, dan ranah psikomotoris (Sudjana, 2009:22).

Dari pendapat-pendapat para ahli diatas, dapat disimpulkan bahwa hasil belajar adalah apresiasi atas usaha atau kerja keras dalam penuntasan konsep-konsep teoritik selama proses pembelajaran serta adanya perubahan tingkah laku. Hasil belajar juga dimaksudkan untuk memotivasi siswa agar lebih bersemangat dan meningkatkan hasil belajarnya lagi.

2. Faktor-faktor yang mempengaruhi hasil belajar yaitu :

Hasil belajar yang dicapai siswa dalam proses pembelajaran tidak dapat terlepas dari faktor-faktor yang dapat mempengaruhinya. Untuk itu Syah, (2006:144) mengemukakan faktor-faktor yang mempengaruhi hasil belajar siswa terdiri dari dua faktor yaitu faktor yang datangnya dari individu siswa (Internal factor), dan faktor yang dating dari luar diri individu siswa (Eksternal factor). Keduanya dapat dijelaskan sebagai berikut:

a. Faktor internal anak, meliputi

1) Faktor psikis (jasmani)

Kondisi umum jasmani yang menandai dapat mempengaruhi semangat dan intensitas anak dalam mengikuti pelajaran.

2) Faktor psikologis (kejiwaan)

Faktor yang termasuk aspek psikologis yang dapat mempengaruhi kualitas perolehan hasil belajar siswa antara lain:
a) Intelegensi
b) Sikap
c) Bakat
d) Minat
e) Motivasi 
b. Faktor eksternal anak, meliputi:

1) Faktor lingkungan sosial, seperti para guru, staf admistrasi dan teman-teman sekelas.

2) Faktor internal non sosial, seperti sarana dan prasarana sekolah/belajar, letaknya rumah tempat tinggal keluarga, keadaan cuaca dan waktu belajar yang digunakan anak.

3) Faktor pendekatan belajar, yaitu cara guru mengajar, maupun metode, model dan media pembelajaran yang digunakan.

3. Macam-macam Hasil Belajar

Pada prinsipnya, pengungkapan hasil belajar ideal meliputi segenap ranah psikologis yang berubah sebagai akibat pengalaman dan proses belajar siswa. Kunci pokok untuk memperoleh ukuran dan data hasil belajar siswa adalah mengetahui garis-garis besar indikator (petunjuk adanya prestasi belajar) kemudian dikaitkan dengan jenis-jenis prestasi yang hendak diukur .

Menurut Bloom (Kamdi, 2010:6) menyatakan bahwa "tujuan belajar siswa diarahkan untuk mencapai ketiga ranah. Ketiga ranah tersebut adalah ranah kognitif, afektif, dan psikomotorik". Melalui ketiga ranah ini pula akan terlihat tingkat keberhasilan siswa dalam menerima hasil pembelajaran atau ketercapaian siswa dalam penerimaan pembelajaran. dengan kata lain prestasi belajar akan terukur melalui ketercapaian siswa dalam penguasaan ketiga ranah tersebut.

Untuk lebih spesifiknya, Latuheru $(2002,69)$ merinci sebagai berikut;

a. Cognitive Domain (Ranah Kognitif), yang berisi perilaku-perilaku yang menekankan aspek intelektual, seperti pengetahuan, pengertian dan keterampilan berfikir.

b. Affective Domain (Ranah Afektif) berisi perilaku-perilaku yang menekankan aspek perasaan dan emosi seperti minat, sikap, apresiasi, dan cara penyesuaian diri. Tujuan pendidikan ranah afektif adalah 
hasil belajar atau kemampuan yang berhubungan dengan sikap atau afektif.

c. Psychomotor Domain (Ranah Psikomotor) berisi perilaku-perilaku yang menekankan aspek keterampilan motorik, karena keterampilan ini (kognitif, afektif, dan psikomotor) tersebut tidak dapat berdiri sendiri-sendiri tetapi merupakan satu kesatuan, dan harus dipandang sebagai sasaran hasil belajar.

4. Jenis-jenis Penilaian Hasil Belajar

a. Pengertian Penilaian

Penilaian merupakan suatu proses sistematis meliputi pengumpulas informasi (angka, deskripsi verbal/ unjuk kerja), analisis, interprestasi informasi untuk membuat keputusan.

PERMENDIKNAS No. 20 tahun 2007 tentang standar penilaian pendidikan mendefinisikan bahwa penilaian pendidikan adalah proses pengumpulan dan pengolahan informasi untuk menentukan pencapaian hasil belajar peserta didik.

Menilai adalah mengambil suatu keputusan terhadap sesuatu dengan ukuran baik buruk. Penilaian bersifat kualitatif, Arikunto (2009:3). Penilaian dapat disimpulkan sebagai pemberian keputusan untuk kepentingan tertentu yang diambil dari pengumpulan dan pengolahan informasi.

Tes merupakan alat penilaian terhadap seorang individu yang dilakukan secara komperhensip terhadap evaluasi suatu program. Instrumen atau alat penilaian meliputi substansi ( bahan atau kompetensi yang akan diujikan), konstruksi ( tata penulisan pada lembar ujian), dan bahasa ( tata bahasa yang baku dan komunikatif). Penilaian pendidikan dilaksanakan oleh pendidik, satuan pendidikan dan pemerintah.

b. Jenis-jenis Penilaian

Jenis penilaian berdasarkan waktu penilaian, meliputi:

1) Tes formatif 
Adalah penilaian yang dilakukan selama proses pembelajaran berlangsung. Penilaian formatif berorientasi pada proses, yang akan memberikan informasi kepada guru apakah program atau proses belajar mengajar masih perlu diperbaiki.

2) Tes sumatif

Penilaian yang dilaksanakan pada akhir unit program misalnya penilaian yang dilaksanakan pada akhir caturwulan, akhir semester atau akhir tahun. Tujuan penilaian ini adalah untuk mengetahui hasil yang dicapai oleh para siswa, yakni seberapa jauh siswa telah mencapai kompetensi yang ditetapkan dalam kurikulum. Penilaian ini berorientasi pada produk/hasil.

3) Tes Subsumatif

Penilaian yang meliputi sejumlah bahan pengajaran tertentu yang telah di ajarkan pada waktu tertentu. Tes subsumatif biasanya digunakan setelah selesai pokok bahasan (ujian blok). Tujuan penilaian ini adalah untuk memperoleh gambaran daya serap peserta didik. Hasil tes subsumatif dimanfaatkan untuk memperbaiki proses belajar mengajar dan diperhitungkan dalam menentukan nilai rapor.

Dalam penelitian ini pedoman penilaian yang digunakan adalah tes formatif dan tes subsumatif, karena dalam penelitian ini pelaksanaan penilaian pembelajaran dilakukan pada setiap selesai pembelajaran dan setelah selesai akhir bab.

\section{MODEL PEMBELAJARAN INSIDE OUTSIDE CIRCLE (IOC) UNTUK MENINGKATKAN HASIL BELAJAR.}

Model Pembelajaran Inside outside circle (IOC) dalam proses pembelajaran ternyata dapat meningkatan hasil belajar secara signifikan. Secara umum, model pembelajaran memiliki kemampuan untuk mempermudah pemberian informasi sehingga materi yang disampaikan lebih 
mudah tersampaikan, karena model pembelajaran merupakan salah satu komponen utama dalam menciptakan suasana yang aktif, inovatif dan menyenangkan. Penggunaan model pembelajaran juga dapat membantu anak untuk belajar secara mandiri atau kelompok dengan baik, pengambilan materi yang tepat dan luas serta erat dengan kehidupan sehari-hari dapat membantu siswa lebih mudah mengeksplor kemampuannya dalam berfikir dan berbicara, sehingga siswa dengan mudah bisa mengaikatkan materi yang ada dengan pengalaman dan fakta yang mereka temukan di kehidupan sehari-hari.

Tahapan-tahapan dalam model pembelajaran Inside outside circle dimulai dengan mengeksplore pengetahuan awal siswa terhadap materi yang akan diajarkan, dengan mencoba mengaitkan materi dengan pengalaman atau hal-hal yang dijumpai Penyampaian materi dengan model pembelajaran Inside outside circle yang digunakan, dengan mengintruksikan siswa untuk memulai kegiatan. Dari hasil data yang telah di dapat bahwa penerapan pembelajaran dengan menggunakan model Inside outside circle secara keseluruhan dengan baik dan kriterian perolehan tinggi, kenaikan hasil yang diperoleh disebabkan karena pemahaman siswa semakin baik siswa pun semakin terbiasa dengan pembelajaran menggunakan model pembelajaran Inside outside circle, siswa sudah banyak yang tidak kebingungan, siswa juga terlihat aktif, siswa juga terlihat menjadi lebih mudah dalam bekerjasama dalam menyelesaikan masalah yang ada karena siswa sudah banyak mendapatkan informasi. Berdasarkan perolehan hasil di atas penerapan model pembelajaran Inside outside circle dapat dikategorikan baik.

Hal ini sesuai dengan hasil penelitian dengan penggunaan Kooperatif Insid-Outside-Circle yang dilakukan oleh Nurul Hasanah menunjukkan terdapat peningkatan hasil belajar dan keaktifan siswa di kelas V SDN Kidul Dalem 02, dan penelitian yang dilakukan oleh Rizky Hanifudin dengan model yang sama memperoleh hasil penelitian yang menunjukkan rata-rata aktifitas dan hasil belajar siswa mengalami peningkatan.

Peningkatan hasil belajar ini disebabkan karena penggunaan model pembelajaran Inside Outside Cirlce dapat membantu siswa untuk 
mempermudah siswa untuk mendapatkan dan mengolah informasi, bekerjasama, dan meningkatkan keterampilan berkomunikasi. Hal ini sejalan dengan yang dikemukakan oleh Lie, (2008:65) bahwa Keunggulan dari teknik pembelajaran IOC adalah adanya struktur yang jelas dan memungkinkan siswa untuk berbagi dengan pasangan yang berbeda dengan singkat dan teratur. Selain itu, siswa bekerja dengan sesama dalam suasana dan mempunyai banyak kesempatan untuk mengolah informasi dan meningkatkan keterampilan berkomunikasi, model IOC juga baik untuk digunakan semua tingkatan usia dan mata pelajaran.

1. Adapun kendala-kendala yang dihadapi pada saat penerapan model pembelajaran Insaide Outside Circle (IOC) menurut lie (2008), adalah bahwa kekurangan dalam penerapan model inside outside circle ada 2 yaitu membutuhkan ruangan yang besar dan waktu yang terlalu lama sehingga siswa tidak konsentrasi dan disalah gunakan untuk bergurau.

Penerapan model pembelajaran Inside outside circle digunakan dalam materi pelajaran apa saja. Penerapan model pembelajaran Inside outside circle pada pelajaran dapat membantu siswa menemukan ide-ide baru, terampil berbicara, kreatifitas siswa pun muncul dalam kegiatan pembelajaran. Dan selama pembelajaranpu siswa antusias menerima materi dan menyelesaikan soal-soal dan tugas yang diberikan.

Model pembelajaran ini juga mampu menciptakan interaksi siswa yang baik, memberikan peluang kepada siswa agar mengemukakan dan membahas suatu pandangnnya sendiri, memumgkinkan siswa untuk mengembangkan pengetahuan, kemampuan dan keterampilannya dalam belajar sehingga siswa lebih aktif dan giat dalam kegiatan pembelajaran disekolah karena lebih banyak mendapat kesempatan untuk berbicara, inisiatif, menentukan pilihan dan mengembangkan kebiasaan yang baik. Hal ini sesuai dengan teori yang dikemukakan Isjoni, (2009:8) Model pembelajaran merupakan strategi yang digunakan oleh guru untuk meningkatkan motivasi belajar, sikap belajar dikalangan siswa, mampu berpikir kritis, memiliki keterampilan sosial, dan pencapaian hasil pembelajaran yang lebih optimal. 
Menurut lie (2008:65), teknik pembelajaran IOC adalah teknik pembelajaran yang dikembangkan oleh Spencer Kagan untuk memberikan kesempatan pada siswa agar saling berbagi informasi pada saat yang bersamaan. Pendekatan ini bisa digunakan dalam beberapa mata pelajaran, seperti: ilmu pengetahuan sosial, agama, matematika, dan bahasa. Bahan pelajaran yang paling cocok digunakan dengan model IOC ini adalah bahan yang membutuhkan pertukaran pikiran dan informasi antar siswa.

\section{E. SIMPULAN}

1. Model pembelajaran Inside Outside Circle (IOC) adalah model pembelajaran dengan sistem dua lingkaran yakni lingkaran luar dan lingkaran dalam sehingga siswa membentuk posisi yang saling berhadapan setelah itu siswa saling berbagi informasi, pemberian informasi dimulai dari siswa yang berada di lingkaran dalam. Agar informasi yang di dapat bisa lebih banyak dan beragam maka dilakukan perputaran sehingga membentuk pasangan yang baru. Hal tersebut mungkin dimaksudkan agar siswa aktif dan diharapkan mampu untuk bekerja secara individu maupun bekerja secara tim.

2. Hasil belajar pada siswa adalah kemampuan-kemampuan yang dimiliki siswa setelah ia menerima pengalaman belajarnya. Hasil belajar siswa hakikatnya adalah perubahan mencakup bidang kognitif, afektif dan psikomotoris yang berorientasi pada proses belajar yang dialami siswa

3. Penggunaan model Inside Outside Circle dalam proses pembelajaran ternyata dapat meningkatan hasil belajar secara signifikan. Secara umum, model pembelajaran memiliki kemampuan untuk mempermudah pemberian informasi sehingga materi yang disampaikan lebih mudah tersampaikan, karena model pembelajaran merupakan salah satu komponen utama dalam menciptakan suasana yang aktif, inovatif dan menyenangkan 


\section{DAFTAR PUSTAKA}

Anita Lie, 2008, Cooperative Learning: Mempraktikkan Cooperative Learning Di Ruang-ruang Kelas, Jakarta: Grasindo.

Anonim, 2012. Pengertian Hasil Belajar. http://www.hasiltesguru.com. $12 / 01 / 2014$

Anonim. 2012. Macam-macam Teknik Penilaian Hasil Belajar. http://sumberbelajarangga.wordpress.com. 25/12/2013.

Anonym. Pengaruh Model Pembelajaran IOC terhadap hasil belajar. https://www.google.com/. 12/03/2013

Arikunto, Suharsimi. 2007. Prosedur Penelitian Suatu Pendekatan Praktik. Jakarta: Rineka Cipta.

Arikunto, suharsimi. 2009. Dasar-dasar evaluasi pendidikan. Jakarta : Bumi Aksara

Aunnurrahman, 2009. Belajar dan Pembelajaran. Bandung: Alfabeta

Campbell, Neil A. Dkk. 2004. Biologi. Jakarta: Erlangga

Nana S. Sukmadinata. 2007. Metode Penelitian Pendidikan. Bandung: PT Remaja Rosdakarya.

Nasution. 2004. Didiktik Asas-Asas Mengajar. Jakarta: Bumi Aksara

Permendiknas No 20 tahun 2007. 2007. Standar penilaian pendidikan. Jakarta : Depdiknas.

Somantri, Ating dan Muhidin. 2006. Aplikasi Statistika dalam Penelitian. Bandung: Pustaka Setia

Sudijono, Anas.2010. Pengantar Statistik Pendidikan. Jakarta:Rajawali Pers.

Sudirman. 2001. Interaksi dan Motivasi Belajar Mengajar, Jakarta: PT Raja Grafindo Persada.

Sudjana, Nana. 2011. Penilaian Hasil Proses Belajar Mengajar. Bandung: Remaja Rosdakarya.

Sugiyono. 2009. Statistik Untuk Penelitian. Bandung: Alfabeta.

Sumiati dan Asra. 2007. Metode Pembelajaran. Bandung: CV. Wacana Prima 
Suyatno, 2009. Menjelajah Pembelajaran Inovatif. Sidoarjo: Masmedia Buana Pustaka

Trihendradi, C. 2009. Step By Step SPSS 16 Analisis Data Statistik. Yogyakarta: Penerbit Andi

Turmudi dan Hariri, Sri. 2008. Metode Statistika: Pendekatan Teoritis dan Aplikatif. Malang: UIN-Malang Press

Warsita, Bambang. 2011. Pendidikan Jarak Jauh. Bandung: Remaja Rosdakarya. 